\title{
GLOSSÁRIO DINÂMICO DE TERMOS NA ÁREA DE TECNÓPOLIS, PARQUES TECNOLÓGICOS E INCUBADORAS DE EMPRESAS
}

\author{
Helena Maria Gramiscelli Magalhães, M.A.
}

O mercado livreiro ainda não dispunha de um trabalho tão consistente e completo quanto o Glossário de termos Tecnópolis, Parques Tecnológicos e Incubadoras de Empresas. Isso porque escrever um trabalho desse porte demanda competência e critério.

Iniciativa da Anprotec e do Sebrae, o documento vem atender aos profissionais da área de empreendedorismo, a seus parceiros e a todos os interessados na área de incubação, na medida em que reúne e revê termos prioritários e complementares que durante algumas décadas serviram à comunicação entre os atores e os incentivadores da comunidade empresarial.

A conceituação dos termos reunidos e revisados orienta o leitor comum, porque elucidam de modo simples e claro os vocábulos técnicos, tornando-os acessíveis e desmitificando a idéia de que algumas terminologias estariam restritas a certos campos dos negócios ou a poucas pessoas.

Os termos, esclarecidos com a competência e lucidez próprias de profissionais da área de língua e da ciência, colocam o leitor, ainda que leigos no assunto, em condições de dominar o vocabulário, melhor interagir nos relacionamentos empresariais e mais facilmente ampliar os negócios.

A divisão do glossário facilita a consulta. Listados por ordem alfabética, os termos trazem sua conceituação. O termo base aparece em destaque e os que dele derivam em sub-itens. Um índice remissivo reúne em nove grupos temáticos os conceitos usados pelos pólos, parques tecnológicos e incubadoras. É leitura fluente.

O glossário, resultado de um trabalho conjunto de inúmeros atores, traz a marca inconfundível das organizadoras Rosa Maria Neves da Silva, e Adelaide Maria Coelho Baeta, autoras de outro glossário inédito - Glossário Bilíngüe de Tecnologia e Negócios, editado pela Editora Nova Fronteira, 1998 - que imprimem ao documento um caráter de obra referencial àqueles interessados na execução de projetos e programas de empreendimentos de base tecnológica.

No compito geral, o glossário é leitura imprescindível; obra que faltava à comunidade empresarial. No mais, resta esperar que revisões venham a ser feitas ao glossário para garantir-lhe o cunho de obra sempre atual.

Helena Maria Gramiscelli Magalhães, M.A. 